\title{
EVALUATION OF EFFECTIVE DIFFUSIVITY CORRELATIONS FOR SOYBEANS IN THIN LAYER DRYING
}

\section{ANÁliSE DE CORRELAÇÕES DA DIFUSIVIDADE EFETIVA DE GRÃOS DE SOJA SUBMETIDOS A SECAGEM EM CAMADA FINA}

\author{
F. D’AVILA ${ }^{1, *}$, R. M. URNAU' ${ }^{1}$, A. M. Z. BLAUTH ${ }^{1}$ and M. F. P. MOREIRA ${ }^{1}$ \\ ${ }^{1}$ Western Paraná State University, Department of Chemical Engineering, Toledo, Paraná, Brazil \\ "Felipe d'Avila. Western Paraná State University, Department of Chemical Engineering, Toledo, Paraná, Brazil, Phone: +55 45998204368 \\ e-mail address: felipegdavila@gmail.com (F.D'AVILA).
}

\begin{tabular}{|c|}
\hline A R T I C LE INFO \\
\hline $\begin{array}{l}\text { Article history: } \\
\text { Received 2020-07-31 } \\
\text { Accepted 2020-10-20 } \\
\text { Available online 2020-10-20 }\end{array}$ \\
\hline $\begin{array}{l}\text { palavras-chave } \\
\text { Transferência de massa } \\
\text { Lei de Fick } \\
\text { Método da tangente }\end{array}$ \\
\hline $\begin{array}{l}\frac{k e y w o r d s}{\text { Mass transfer }} \\
\text { Fick's Law } \\
\text { Slope method }\end{array}$ \\
\hline
\end{tabular}

\begin{abstract}
A B S T R A C T
Soybean is one of the main crops in the world and drying plays an important role in maintaining the quality of the grains. The present study aimed to evaluate different existing models regarding the ability to predict the effective diffusivity of soybeans, an important parameter in studies of the operation. The slope method was used to determine the effective diffusivity, starting from the second Fick's Law, with negligible shrinkage and external mass transfer resistance. The parameter was analyzed as being dependent on both temperature and moisture content. The correlation proposed by Dotto et al. (2018) was the one with the lowest average error $(0.048 \%)$ for the consideration of an average effective diffusivity. In order to consider a punctual effective diffusivity, a modification to this model was proposed, resulting in a maximum error of $2.6 \%$.

RES UM O

A soja é uma das principais lavouras mundiais e a secagem desempenha importante papel na manutenção da qualidade dos grãos. O presente estudo teve como objetivo avaliar diferentes modelos existentes quanto a capacidade de previsão da difusividade efetiva da soja, parâmetro este importante nos estudos da operação. Utilizou-se o método das tangentes para a determinação da difusividade efetiva, a partir da segunda Lei de Fick, desprezando encolhimento e a resistência externa a transferência de massa. O parâmetro foi analisado como sendo dependente tanto da temperatura como do teor de umidade. A correlação proposta por Dotto et al. (2018) foi a que apresentou menor erro médio (0,048\%) para a consideração de uma difusividade efetiva média. Para a consideração de uma difusividade efetiva pontual, uma modificação a esse modelo foi proposta, resultando em um erro máximo de $2,6 \%$.
\end{abstract}




\section{NOM E N C L A T UR E}

$D_{e f f} \quad$ Effective moisture diffusivity, $\mathrm{m}^{2} \mathrm{~s}^{-1}$

Fo Fourier number, dimensionless

MR Moisture ratio, dimensionless

$n \quad$ Term of the series, dimensionless

$R \quad$ Particle radius, [m]

$R^{2} \quad$ Coefficient of determination, dimensionless

$r \quad$ Radial coordinate, $[\mathrm{m}]$

$R_{g} \quad$ Universal gas constant, [kJ/mol K]

RH Relative humidity, dimensionless

$T \quad$ Air drying temperature, $\left[{ }^{\circ} \mathrm{C}\right]$

$t \quad$ Time, [s]

$X \quad$ Moisture content at any time, [ $\mathrm{kg} \mathrm{H}_{2} \mathrm{O} / \mathrm{kg}$ dry mass]

$X_{0} \quad$ Initial moisture content, [ $\mathrm{kg} \mathrm{H}_{2} \mathrm{O} / \mathrm{kg}$ dry mass]

$X_{e} \quad$ Equilibrium moisture content, [ $\mathrm{kg} \mathrm{H}_{2} \mathrm{O} / \mathrm{kg}$ dry mass]

$W_{d s} \quad$ Dry solid weight, $[\mathrm{kg}]$

$W_{s} \quad$ Sample weight at any time, $[\mathrm{kg}]$

\section{INTRODUCTION}

Soybean (Glycine max L. Merril) is a shrub of the legume family, domesticated by the Chinese, around 5,000 years ago. Alongside rice, corn and wheat it is one of the main crops on the planet and Brazil is among the largest world producers (Hasse, 1996; USDA, 2020). In 2019, the second largest Brazilian soybean production in the historical series of Conab was consolidated, with an estimated production of 3.17 tons per hectare and an increase of $1.8 \%$ in the planted area (CONAB, 2019).

In order to avoid microbial contamination or pest attack, early soy harvesting is recommended (Ribeiro et al., 2005), which can lead to grains with high moisture content in storage. Thus, the control of the moisture content and the temperature of the soybean during grain storage are of fundamental importance to avoid physical-chemical and microbiological deterioration, in addition to guaranteeing the quality of the product (Krzyzanowski et al., 2008; Mohler, 2010; Moreira et al., 2015).

Several works have been developed in order to contribute with information about the drying step in the soy production process, analyzing the balance isotherms, thermal diffusivity, thin layer drying, among others (Wiriyaumpaiwong et al., 2003; Barrozo et al., 2006; Oro et al., 2010; Cruz et al., 2011; Lorensi \& Moreira, 2011; Moreira et al., 2015).

Effective diffusivity is a coefficient capable of describing the speed with which water is removed from a material. This parameter groups all the phenomena involved in the mass transfer of the water from the material (Lewis, 1921).

Understanding the phenomena that happen during the process is fundamental in the development and optimization of equipment. The usual relationship of diffusivity with the Arrhenius-type equation is not satisfactory in several materials
(Touil et al., 2014; Dotto et al., 2018).

This work aimed to evaluate the dependence of effective diffusivity with temperature and moisture content, in addition to the predictive capacity of different models for the same parameter.

\section{MATERIALS AND METHODS}

The soybeans used in this study was provided by COAMO Agoindustrial Cooperativa (Paraná - Brazil), from the 2015, 2016 and 2017 harvest.

In order to obtain a standard distribution, the grains were characterized in a sample space of 30 units. The physical dimensions were obtained through digital image processing, using the ImageJ software, developed by National Institutes of Health. The particles were approximated to an ellipsoidal shape, as shown in Figure 1, with dimensions named as a, b and $\mathrm{c}$ (Guedes et al., 2011).

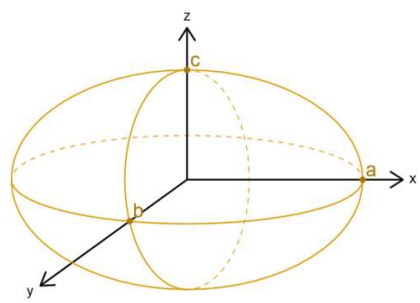

Figure 1 - Schematic of the approximate geometry for soybeans.

Thirteen drying experiments were conducted in replicate, at different conditions of air temperature (from 30 to $63{ }^{\circ} \mathrm{C}$ ) and air speed (from 0.1 to $1.1 \mathrm{~m} \mathrm{~s}^{-1}$ ). Before each experiment, the necessary operating conditions were established in the dryer equipment and the stationary regime was awaited. The total weight of the grains in the dryer was measured during the process, for a period of 5 hours.

The moisture content of the samples was determined using the methodology proposed by MAPA (2009), by drying in an oven at $105^{\circ} \mathrm{C}$, until constant weight and was calculated by Equation 1 .

$X=\frac{W_{s}-W_{d s}}{W_{d s}}$

where $X$ is the moisture content at any time, $\left[\mathrm{kg} \mathrm{H} \mathrm{H}_{2} \mathrm{O} / \mathrm{kg}\right.$ dry mass], $W_{s}$ is the sample weight at any time, $[\mathrm{kg}]$, and $W_{d s}$ is the dry solid weight, [kg dry mass].

Due to the time set for the experiments, not all kinetics reached equilibrium. Thus, the Modified Halsey Equation (Osborn et al., 1989) was used to determine the equilibrium moisture content. The Equation 2 with the empirical constants for soybeans, determined by Finkler and Moreira (2010), is as follows:

$X_{e}=\left(\frac{\exp (-0.0124 \cdot T+3.2286)}{-\ln (R H)}\right)^{1 / 1.4522}$

where $X_{e}$ is the equilibrium moisture content, [ $\mathrm{kg} \mathrm{H} \mathrm{H}_{2} \mathrm{O} / \mathrm{kg}$ dry mass], $T$ is the temperature, $\left[{ }^{\circ} \mathrm{C}\right]$, and $\mathrm{RH}$ is the relative humidity of the drying air, dimensionless. 
The effective diffusivity was calculated with the aid of the slope method, based on the diffusive model of Fick's second Law of diffusion, for spherical coordinates, in a non-stationary state, negligible external mass transfer resistance (Barrozo et al., 2006) and negligible shrinkage as shown in Equation 3.

$\frac{\partial X}{\partial t}=\frac{D_{e f f}}{r^{2}}\left[\frac{\partial}{\partial r}\left(r^{2} \frac{\partial X}{\partial r}\right)\right]$

where $t$ is time, [s], $r$ is the radial coordinate, [m], and $D_{\text {eff }}$ is the effective diffusivity, $\left[\mathrm{m}^{2} \mathrm{~s}^{-1}\right]$.

A uniform moisture content was assumed as an initial condition, as seen in Equation 4. Due to the particle geometry, a symmetry boundary condition was defined, according to Equation 5. Finally, the second boundary condition was the neglect of external resistance (Barrozo et al., 2006), as explained in Equation 6.

$X(r, 0)=X_{0}$

$\frac{\partial X}{\partial r}(0, t)=0$

$X(R, t)=X_{e}$

where $X_{0}$ is the initial moisture content, [ $\mathrm{kg} \mathrm{H}_{2} \mathrm{O} / \mathrm{kg}$ dry mass], and $R$ is the particle radius, [m].

The formulation solution is represented by the following
Equation 7 (Crank, 1975):

$\overline{M R}=\frac{X-X_{e}}{X_{0}-X_{e}}=\frac{6}{\pi^{2}} \cdot \sum_{n=1}^{\infty}\left\{\frac{1}{n^{2}} \cdot \exp \left[\frac{-(n \cdot \pi)^{2} \cdot D_{e f f} \cdot t}{R^{2}}\right]\right\}$

where $M R$ is the moisture ratio, dimensionless, $\mathrm{n}$ the term of the series, dimensionless.

From the above, the effective diffusivity can be determined by the following Equation 8:

$$
\begin{aligned}
& D_{\text {eff }}=\left[\frac{(d \overline{M R} / d t)_{\exp }}{(d \overline{M R} / d F o)_{\text {theo }}}\right] \cdot R^{2} \\
& \left(\frac{d \overline{M R}}{d F o}\right)_{\text {theo }}=-6 \cdot \sum_{n=1}^{\infty}\left\{\exp \left[-(n \cdot \pi)^{2} \cdot F o\right]\right\}
\end{aligned}
$$

where $F o$ is the Fourier number, dimensionless, given by Equation 10.

$F o=\frac{D_{e f f} \cdot t}{R^{2}}$

Effective diffusivity models available in the literature, shown in Table 1, and proposed in this study were adjusted to the experimental values. The parameters of each model were adjusted using the Levenberg-Marquardt optimization method. All calculation was performed using the Scilab ${ }^{\circledR}$ software and Python.

Table 1 - Models of effective diffusivity.

Arrhenius-type equation

$$
D_{\text {eff }}(T)=D_{0} \cdot \exp \left(-E_{a} / R_{g} \cdot T\right)
$$

Chemkhi \& Zagrouba, 2005

$$
D_{\text {eff }}(X)=a \cdot X^{2}+b \cdot X+c
$$

Azzouz et al., 2002

$$
D_{\text {eff }}(T, X)=D_{0} \cdot \exp \left(-E_{a} / R_{g} \cdot T\right) \cdot \exp (-(a \cdot T+b) \cdot X)
$$

Touil et al., 2014

$$
D_{e f f}(T, X)=a+b \cdot X+c \cdot T+d \cdot X^{2}+e \cdot T^{2}+f \cdot X \cdot T
$$

Barrozo et al., 2006

$$
D_{e f f} / R^{2}(T, X)=a \cdot \exp \left(-E_{a} / R_{g} \cdot T\right) \cdot \exp (b \cdot X)
$$

Dotto et al., 2018

$$
\ln \left(1 / D_{\text {eff }}\right)=\left(a_{1} \cdot T^{a_{2}}+a_{3}\right) \cdot W^{2}+\left(b_{1} \cdot T^{b_{2}}+b_{3}\right) \cdot W+\left(c_{1} \cdot T^{c_{2}}+c_{3}\right)
$$

\section{RESULTS AND DISCUSSION}

\subsection{Soybeans characteristics}

The analyzed soybeans showed an average diameter of $6.572 \mathrm{~mm}$ and an average sphericity of 0.89 . The values corroborate studies found in the literature (Guedes et al., 2011; Bortolotti, 2012). The average initial moisture content, on a dry basis, was $18.41 \%$, a value close to the moisture content under different harvest conditions (Tsukahara et al., 2016).

\subsection{Effect of temperature and moisture content}

Figure 2 shows some drying kinetics obtained at different temperatures. They corroborate literature studies for the grain, highlighting the high temperature dependence in the process (Genaro et al., 2017; Bortolaia, 2011; Möhler, 2010).

In all experimental conditions, $D_{\text {eff }}$ was estimated using the slope method, for each time interval. Usually, the effective diffusivity was treated as constant during the drying operation, being dependent solely on temperature (Steffe and Singh, 1982). Figure 3 shows the relationship between the effective diffusivity and the moisture ratio, for 2 different temperatures. It is observed an effect provided by both the temperature and the variation of moisture content. 


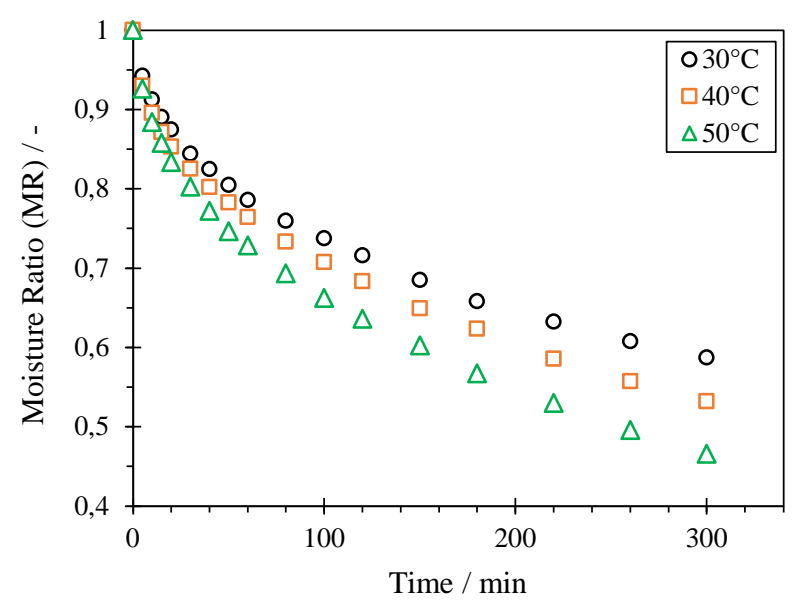

Figure 2 - Moisture ratio curves as a function of time for drying parameterized at temperature.

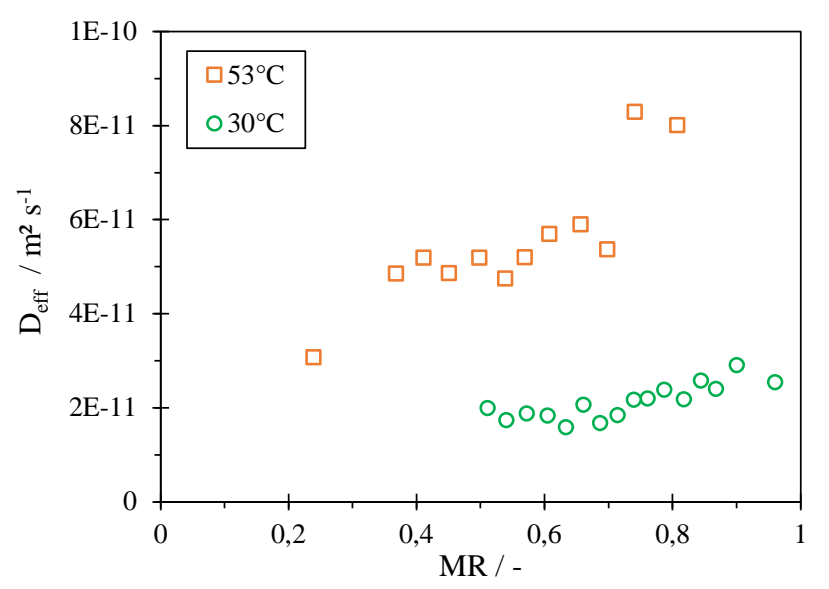

Figure 3 - Influence of moisture content on the effective diffusivity.

Due to the disparity of order of magnitude, the effect of humidity is more evident for the condition of $30{ }^{\circ} \mathrm{C}$ if the diffusivity was normalized by its average value, as shown in Figure 4.

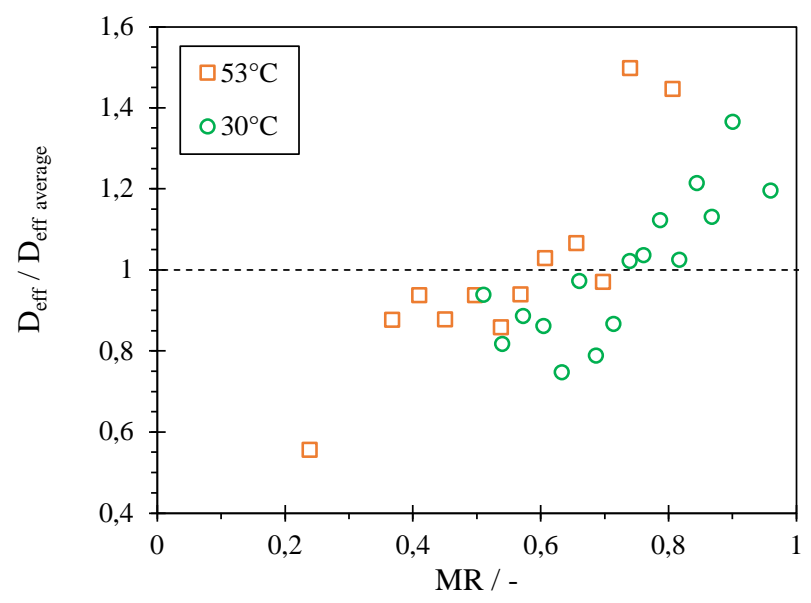

Figure 4 - Effective diffusivity normalized as a function of moisture ratio for two different temperatures.
Six different models proposed in the literature were adjusted to the experimental effective diffusivity data obtained. Such adjustment had been carried out in two different ways: considering the value as constant in the process, having an average temperature and moisture content and considering these values as variables throughout the process. The models are shown in Table 1.

\subsection{Analysis of average effective diffusivity}

The first model studied was the Arrhenius-type equation. Was the commonly used in the literature (Steffe and Singh, 1982; Babalis and Belessiotis, 2004; Kaya et al., 2006). The equation, however, showed a low correlation, even though it described the data trend, as shown in Figure 5.

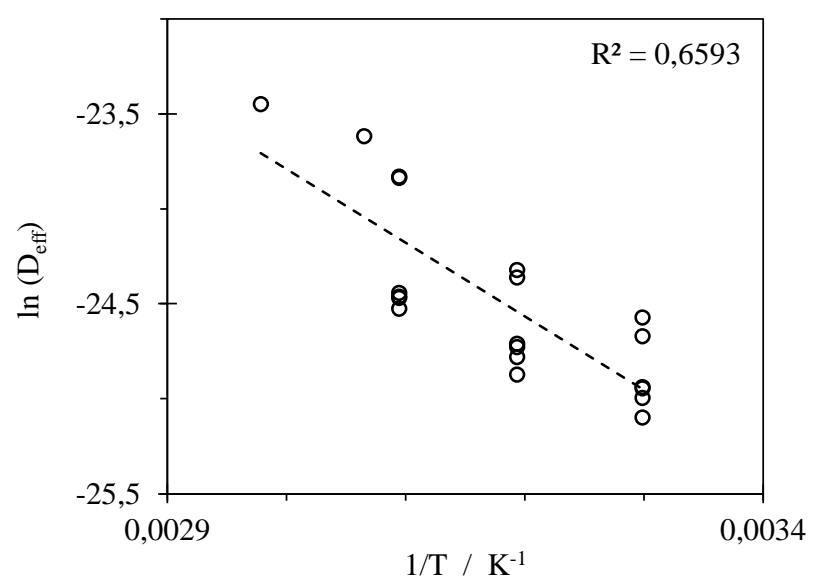

Figure 5 - Arrhenius-type equation fitting for the average experimental data of each drying.

From the model, the activation energy for soybeans can be estimated at approximately $27.77 \mathrm{~kJ} \mathrm{~mol}^{-1}$. Kitic and Viollaz (1984), when studying the drying of soybeans in a thin layer, obtained an activation energy of $28.80 \mathrm{~kJ} \mathrm{~mol}^{-1}$, corroborating the present work. The use of equations of this type ends up neglecting the effects of humidity, seen in this work in Figures 3 and 4 as well as by other authors such as Touil et al. (2014).

Chemkhi and Zagrouba (2005) found that, for clay materials, the effective diffusivity has a more significant relationship with the moisture content than with the temperature. The authors proposed a model that, when adjusted to the data obtained in this study, reached a determination coefficient $\left(\mathrm{R}^{2}\right)$ of 0.5076 and an average error of $20.30 \%$.

Table 2 - Mean percentage error of models fitting.

\begin{tabular}{lcc}
\hline \multicolumn{1}{c}{ Model } & \multicolumn{2}{c}{ Mean error / \% } \\
& Punctual data & Average data \\
\hline Arrhenius-type equation & 29.36 & 21.66 \\
Chemkhi \& Zagrouba, 2005 & 38.83 & 20.30 \\
Azzouz et al., 2002 & 28.14 & 20.90 \\
Touil et al., 2014 & 25.07 & 07.10 \\
Barrozo et al., 2006 & 35.84 & 26.20 \\
Dotto et al., 2018 & 00.94 & 00.05 \\
\hline
\end{tabular}


The models analyzed with dependence on only one variable did not provide a good representation of the experimental data. Different works in the literature studied models dependent on temperature and moisture content, such as Azzouz et al. (2002), Barrozo et al. (2006), Touil et al. (2014) and Dotto et al. (2018). The values for the mean percentage errors for the equations developed by these authors are shown in Table 2, in the column "Average".

It is observed that, in general, all models that consider moisture content and temperature showed lower average errors than those that depend on only one of these. Among the models, Dotto et al. (2018) presented a better fitting, providing an average deviation of $0.048 \%$, as shown in Figure 6 . The parameters obtained were $a_{1}=1.213 \times 10^{-10} \mathrm{~K}^{-1}, a_{2}=4.400$, $a_{3}=12.81, b_{1}=-2.420 \times 10^{-2} \mathrm{~K}^{-1}, b_{2}=1.222, b_{3}=0.1371$, $c_{1}=-8.261 \times 10^{-22} \mathrm{~K}^{-1}, c_{2}=8.261$ and $c_{3}=31.65$.

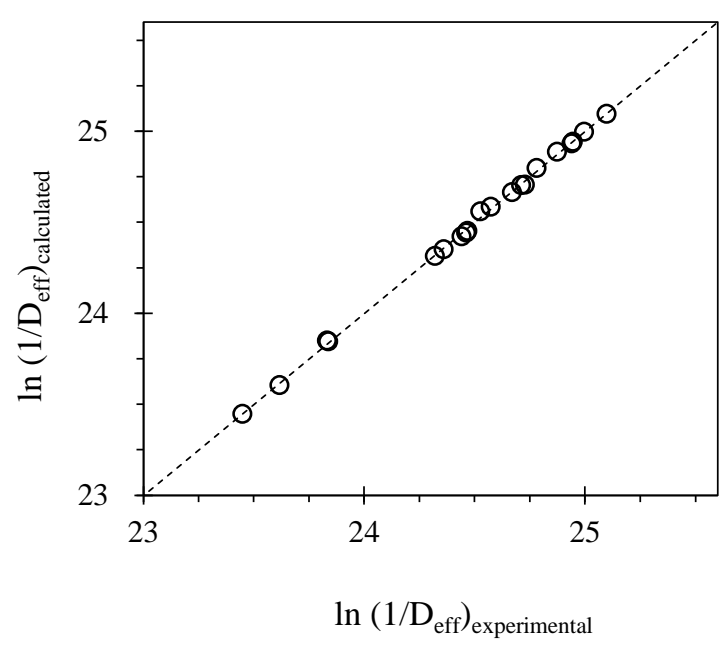

Figure 6 - Correlation between experimental and calculated $D_{\text {eff }}$ values by Dotto model for average values.

However, since the drying process is defined by the decrease in the moisture content of the material and, as already defined, the effective diffusivity depends on this variable, a more precise analysis must take into account its value at every moment, and not only at a midpoint.

\subsection{Analysis of punctual effective diffusivity}

The models already presented in Table 1 were then adjusted to the diffusivity values obtained for each time interval of each drying. The mean percentage errors obtained for each equation are shown in Table 2, in the "Punctual" column. As with the average diffusivity, models dependent on both temperature and moisture content proved to be more effective. Among them, the model by Dotto et al. (2018) again showed less deviation.

In general, the mean error values obtained were significantly higher compared to the consideration of average diffusivities. Such behavior was expected, since the significant increase in the number of data used. While adjusting the average diffusivity, 20 values were used, while adjusting the point data, a total of 320 points were used. This is an important point to pay attention to in the works that deal with prediction of effective diffusivity.
To improve the predictive capacity of the models, a modification to the equation of Dotto et al. (2018) was proposed, according to Equation 12.

$\ln \left(1 / D_{\text {eff }}\right)=\left(a_{1} \cdot T^{6}+a_{2}\right) \cdot X^{2}+\left(b_{1} \cdot T^{6}+b_{2}\right) \cdot X+\left(c_{1} \cdot T^{4}+c_{2}\right)$

When changing the moisture rate to moisture content, the equation showed a reduction in the average percentage error, as shown in Table 3.

Table 3 - Mean percentage error of proposed model fitting.

\begin{tabular}{rll} 
Model & \multicolumn{2}{c}{ Mean error /\% } \\
& Punctual data & Average data \\
\hline Modified Dotto & 0.880 & 0.147 \\
\hline
\end{tabular}

The parameters obtained for Equation 17 were $a_{1}=7.111 \times 10^{-13} \mathrm{~K}^{-1}, a_{2}=-974.5, \quad b_{1}=-2.040 \times 10^{-13} \mathrm{~K}^{-1}$, $b_{2}=277.1, c_{1}=1.882 \times 10^{-9} \mathrm{~K}^{-1}$ and $c_{2}=0.7633$.

\subsection{Comparison between analyzes}

In order to assess the impact of the punctual analysis, the Dotto models with the parameters adjusted for average diffusivity (topic 3.3) and the modified Dotto for punctual diffusivity (topic 3.4) were used to estimate the values of each instant of a drying. Figure 7 and Figure 8 shows the correlation between the predicted data and the experimental data for both models.

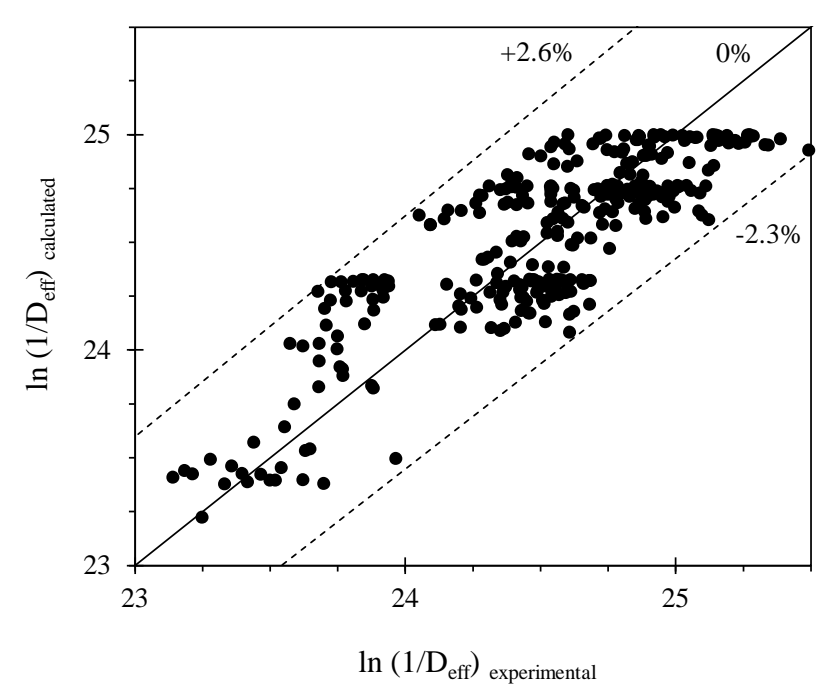

Figure 7 - Correlation between experimental and calculated punctual Deff values by Dotto modified model with parameters obtained from punctual analysis.

It is observed that when using the model adjusted to the average data the errors increase significantly. While the errors did not exceed $2.6 \%$ using the point data model, the use of the average data model showed errors in the range of $-6 \%$ to $19 \%$. 


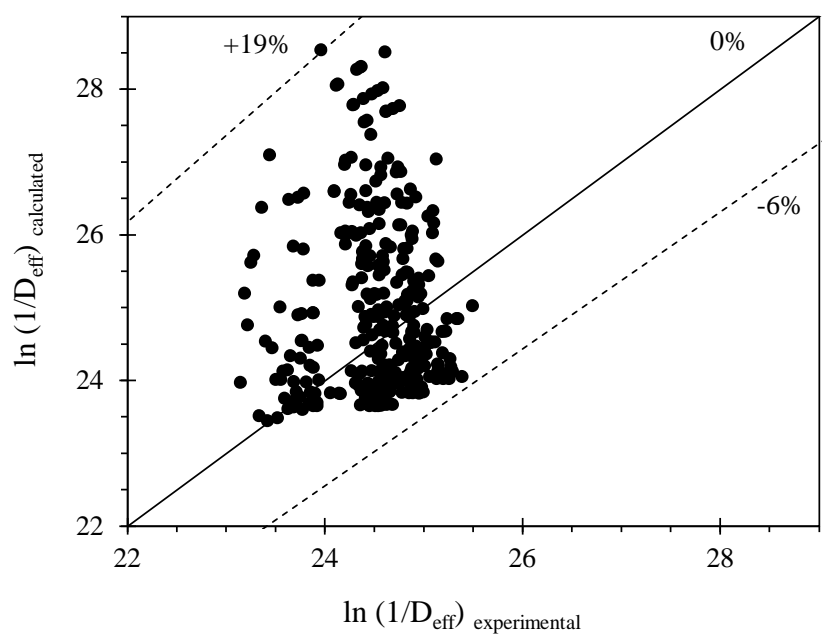

Figure 8 - Correlation between experimental and calculated punctual Deff values by Dotto model with parameters obtained from average analysis.

When comparing the values obtained by the average model with the punctual model, Figure 9 is obtained. Because the model was obtained with average values, it loses its predictive capacity in the initial and final periods of drying, as expected.

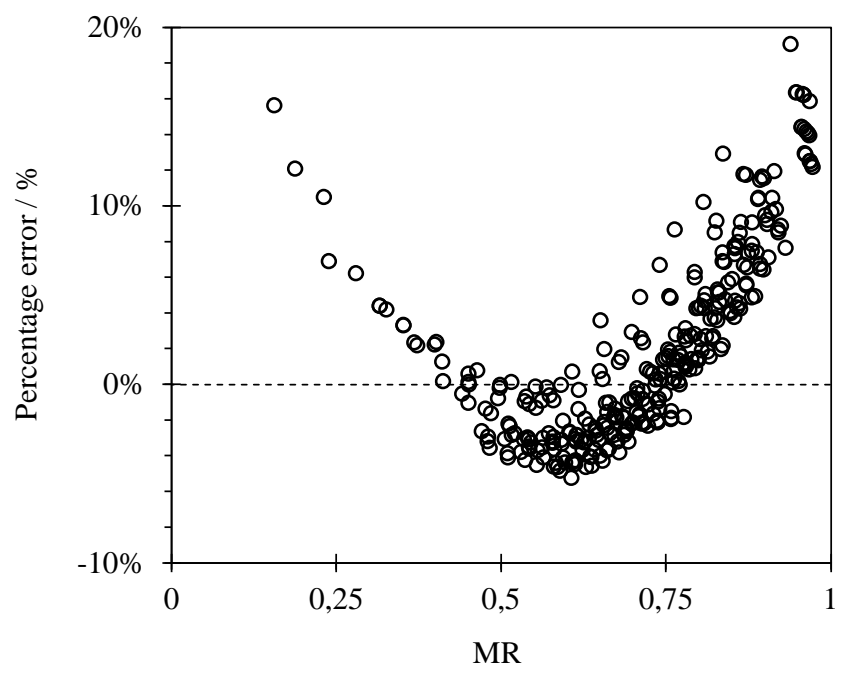

Figure 9 - Comparison between the average and punctual model response.

\section{CONCLUSION}

The activation energy of the soybeans, by the Arrhenius equation, was $27.77 \mathrm{~kJ} \mathrm{~mol}^{-1}$, corroborating the literature. The dependence of effective diffusivity with temperature and moisture content has been proven. The model by Dotto et al. (2018) provided a better adjustment to the average data of a drying operation (average error of $0.048 \%$ ), considering the diffusivity as constant during the process. However, the modification in the Dotto model proposed in this work allowed a prediction of the values of punctual effective diffusivity with a maximum error of $2.6 \%$, for a soybean drying process.

A C K N O W LE D G M E N T S

The authors would like to thank COAMO Agroindustrial Cooperativa and Fundação Araucária for the financial support.

\section{R E F E R E N C E S}

AGROSTAT. Estatística de Comércio Exterior do Agronegócio Brasileiro. Ministério da Agricultura, Pecuária e Abastecimento, 2019.

AZZOUZ, S.; GUIZANI, A.; JOMAA, W.; BELGHITH, A. Moisture diffusivity and drying kinetic equation of convective drying of grapes. Journal of Food Engineering, v. 55, p. 323-330, 2002.

BABALIS, S. J.; BELESSIOTIS, V. G. Influence of the drying conditions on the drying constants and moisture diffusivity during the thin-layer drying of figs, Journal of Food Engineering, v. 65, p. 449-458, 2004.

BARROZO, M. A. S.; HENRIQUE, H. M.; SARTORI, D. J. M.; FREIRE, J. T. The use of the orthogonal collocation method on the study of the drying kinetics of soybean seeds. Journal of Stored Products Research, v. 42, p. 348-356, 2006.

BORTOLOTTI, C. T. Estudo experimental da fluidodinâmica de uma mistura de resíduo de acerola e soja em leito de jorro. 2012. 120f. Dissertação (Mestrado em Engenharia Química) - Universidade Federal de Uberlândia, MG, 2012.

CHEMKHI, S.; ZAGROUBA, F. Water diffusion coefficient in clay material from drying data. Desalination, v.185, p. 491-198, 2005.

CONAB. Sexto Levantamento de Safra. Companhia Nacional de Abastecimento, 2019. Available at: < https://www.conab.gov.br/info-

agro/safras/graos/boletim-da-safra-de-graos>. Accessed on July $20^{\text {th }}, 2020$.

CRANK, J. The Mathematics of Diffusion $2^{\text {nd }}$ ed., London: Clarendon Press, 1975.

CRUZ, M. R.; FINKLER, A. T. J.; MOREIRA, M. F. P. Influência da Espécie na Umidade de Equilíbrio da Soja. In: IX Congresso Brasileiro de Engenharia Química Iniciação Científica, 2011, Maringá.

DOTTO, G. L.; MEILI, L.; TANABE, E. H.; CHIELLE, D. P.; MOREIRA, M. F. P. Evaluation of the mass transfer process on thin layer drying of papaya seeds from the perspective of diffusive models. Heat and Mass Transfer, v. 54, p. 463-471, 2018.

DOYMAZ, I. Drying behaviour of green beans. Journal of Food Engineering, v. 69, p. 161-165, 2005.

FINKLER, A. T. J.; MOREIRA, M. F. P. Análise das isotermas de equilíbrio de adsorção e dessorção da soja. Foz do Iguaçu: Anais do XVIII Congresso Brasileiro de Engenharia Química, 2010.

GENARO, L. B.; BISOGNIN, P. C.; MOREIRA, M. F. P.; SOUSA, R. C.; FREIRE, J. T. Estudo da fluidodinâmica de um leito de jorro para a secagem de soja. In: XXXVIII Congresso Brasileiro de Sistemas Particulados, 2017, Campinas. Anais do XXXVIII Congresso Brasileiro de Sistemas Particulados (ENEMP 2017), p. 1-12.

GUEDES, M. A.; MATA, M. E. R. M. C.; DUARTE, M. E. M.; 
FARIAS, P. A. Caracterização física de grãos de soja utilizando-se processamento digital de imagens. Revista Brasileira de Produtos Agroindustriais, v. 13, n. 3, p. 279-294, 2011.

HASSE, G. O Brasil da Soja - Abrindo Fronteira, Semeando Cidades, Porto Alegre: L\&PM Editores S. A., 1996.

KAYA, A.; AYDIN, O.; DINCER, I. Numerical modeling of heat and mass transfer during forced convection drying of rectangular moist objects, International Journal of Heat and Mass Transfer, v.49, p. 3094-3103, 2006.

KRZYZANOWSKI, F. C.; FRANÇA NETO, J. B.; HENNING, A. A.; COSTG, N. P. O controle de qualidade agregando valor à semente de soja - série sementes. Londrina: Embrapa Soja, 2008.

LEWIS, W. K. The rate of drying of solids materials, The Journal of Industrial and Engineering Chemistry, v. 13, n. 5, p. 427-432, 1921.

LORENSI, J. P.; MOREIRA, M. F. P. Estimativa da difusividade térmica da soja a partir de experimentos de transferência de calor em leito fixo. In: IX Congresso Brasileiro de Engenharia Química - Iniciação Científica, 2011, Maringá.

MAPA. Regras para Análise de Sementes. Brasil: Ministério da Agricultura, Pecuária e Abastecimento, 2009.

MOHLER, B. C. Avaliação das Características de Secagem dos Grãos de Soja. 2010. 43 f. Monografia (Graduação em Engenharia Química) - Universidade Federal do Rio Grande do Sul, Porto Alegre, RS, 2010.

MOREIRA, M. F. P.; CORRÊA, R. G.; FREIRE, J. T. Modelo matemático para previsão da temperatura da soja armazenadas em silos, ENGEVISTA, v. 17, n. 2, p. 240253, 2015.

ORO, A. C. P.; BORGES, B. S.; IGREJA, G.; MOREIRA, M. F. P. Estudo da Transferência de Calor na Massa de Grãos de Soja, de Milho e de Feijão. In: XXXIV Congresso Brasileiro de Sistemas Particulados, 2009, Campinas.

OSBORN, G. S.; WHITE, G. M.; SULAIMAN, A. H.; WELTON, L. R. Predicting equilibrium moisture proportions of soybeans. Transactions of the ASAE, v. 32(6) p. 2109-2113, 1989.

RIBEIRO, D. M.; CORRÊA, P. C.; RODRIGUES, D. H.; GONELI, A. L. D. Análise da variação das propriedades físicas dos grãos de soja durante o processo de secagem, Ciência e Tecnologia de Alimentos, v. 25, p. 611-617, 2005.

STEFFE, J. F.; SINGH, R. P. Diffusion coefficients for predicting rice drying behavior. Journal of Agricultural Engineering Research, v.27, p.489-493, 1982.

TOUIL, A.; CHEMKHI, S.; ZAGROUBA, F. Moisture Diffusivity and Shrinkage of Fruit and Cladode of Opuntia ficus-indica during Infrared Drying. Journal of Food Proceeding, v. 2014, p. 1-9, 2014.

TSUKAHARA, R. Y.; FONSECA, I. C. B.; SILVA, M. A. A.; KOCHINSKI, E. G.; NETO, J. P.; SUYAMA, J. T. Soybean yield as a consequence of harvest delay and environmental conditions. Pesquisa Agropecuária Brasileira, v. 51, n. 8, p. 905-915, 2016.

USDA. World Agricultural Supply and Demand Estimates, United States Department of Agriculture, v. 602, 40p, 2020. Available at: < https://www.usda.gov/oce/commodity/wasde/wasde072 0. pdf $>$. Accessed on July $25^{\text {th }}, 2020$.
WIRIYAUMPAIWONG, S.; SOPONRONNARIT, S.; PRACHAYAWARAKORN, S. Soybean drying by twodimensional spouted bed. Drying Technology, v. 21, 1735-1757, 2003. 